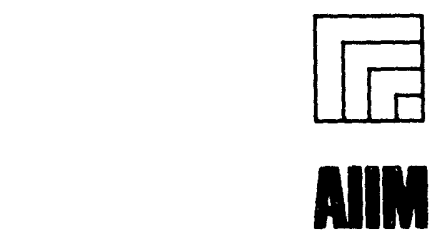

Association for Information and Image Management

1100 Wayne Avenue. Suite 1100

Silver Spring. Maryland 20910

$301: 587-8202$

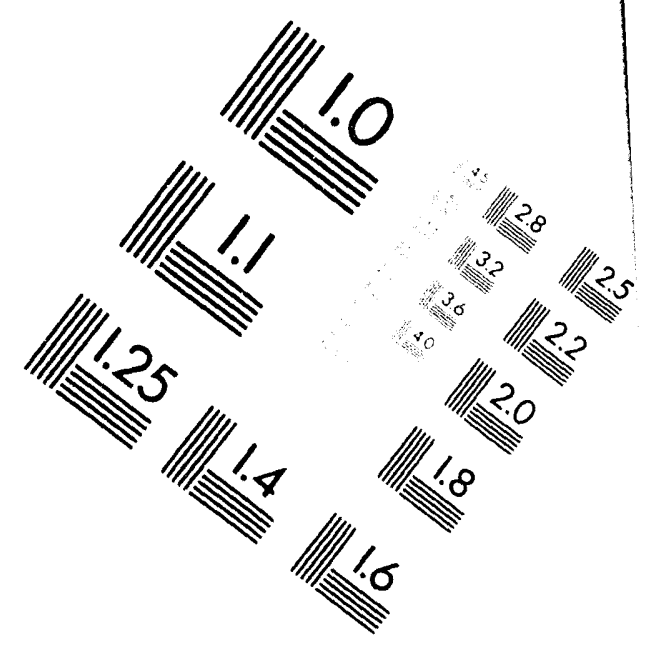

\title{
Centimeter
}

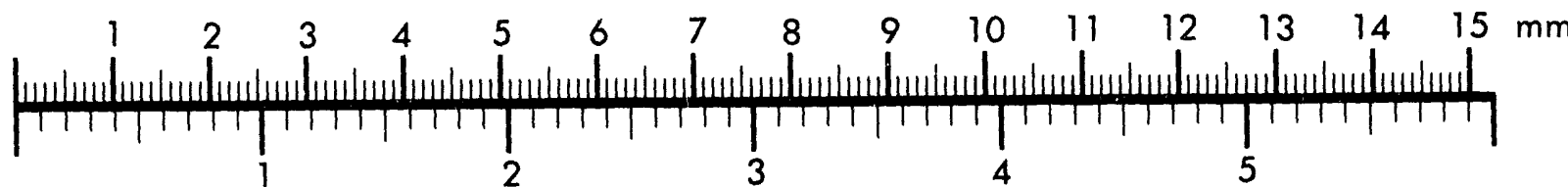

Inches
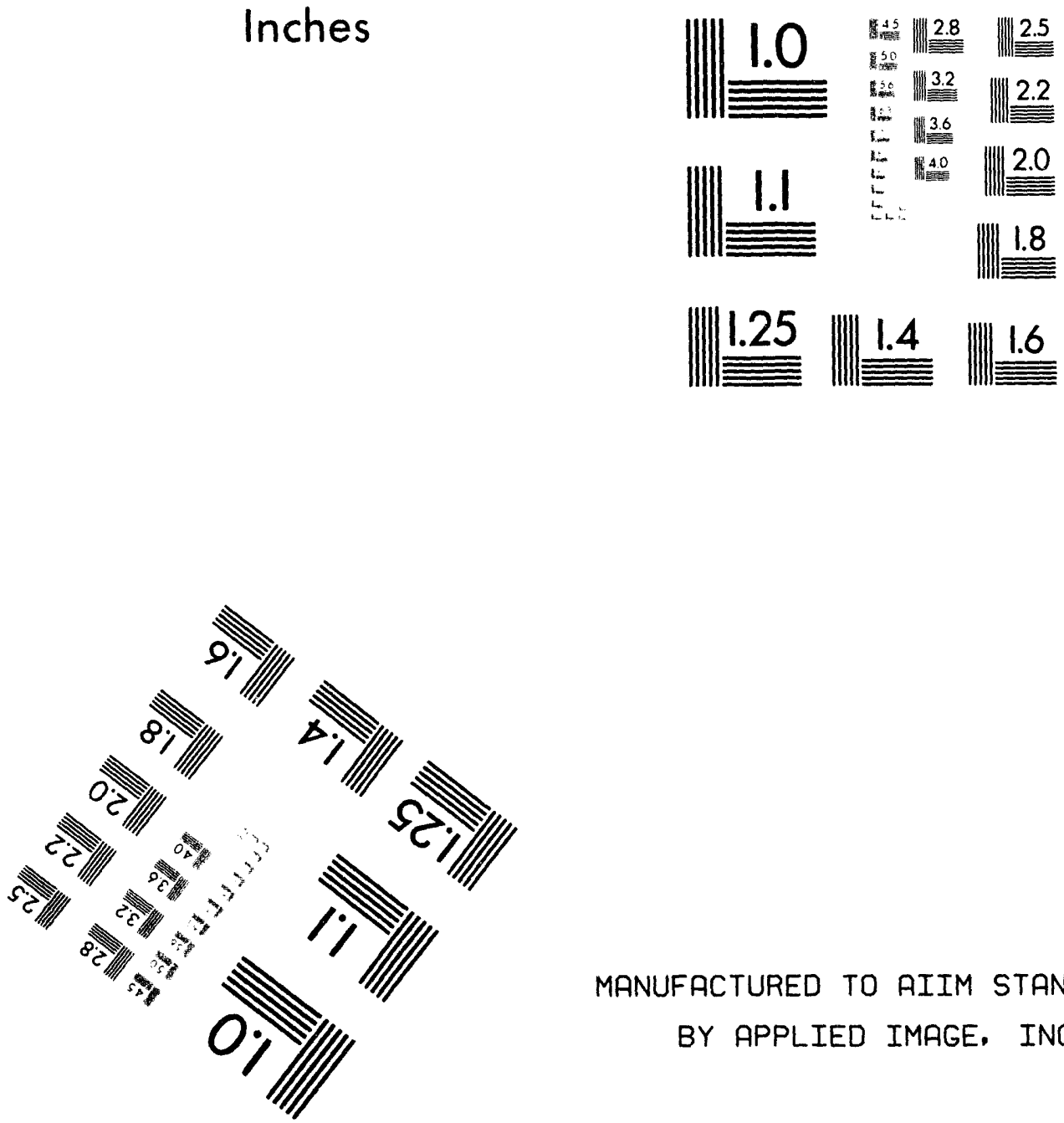

MANUFACTURED TO AIIM STANDARDS

BY APPLIED IMAGE, INC.

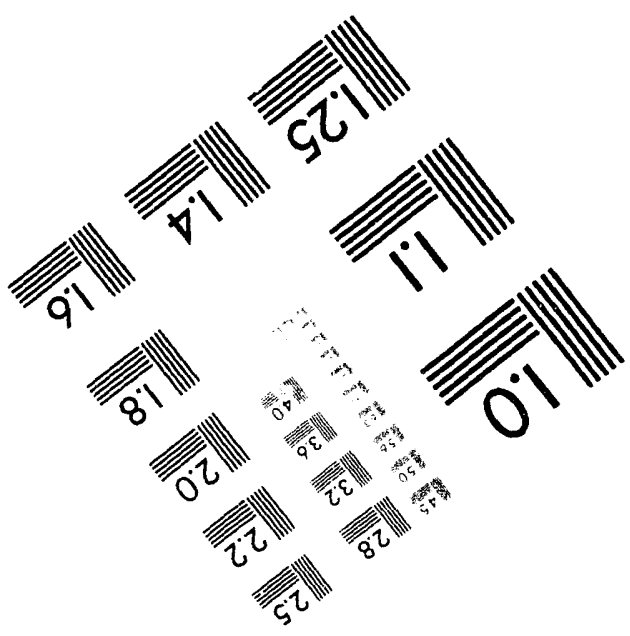



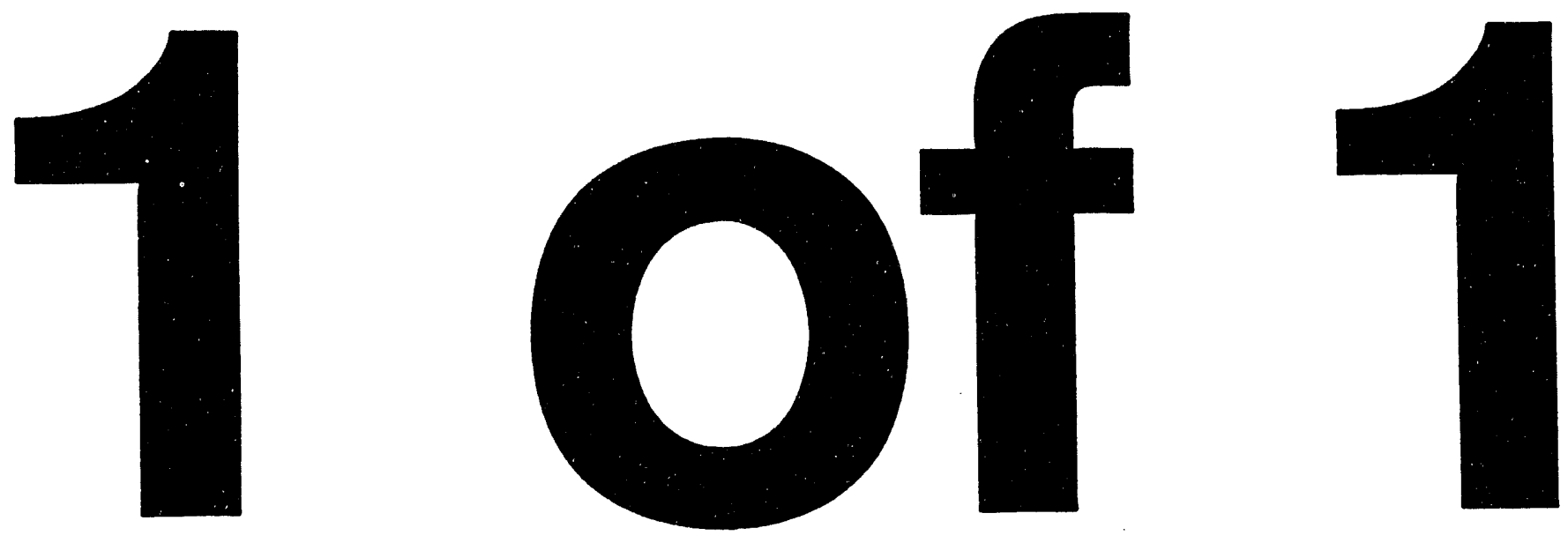


\section{Hazards Assessment for the INEL Landfill Complex}

James K. Knudsen

Michael B. Calley

Published February 1994

Idaho National Engineering Laboratory

EG\&G Idaho, Inc.

Idaho Falls, Idaho 83415

Prepared for the

U.S. Department of Energy

Office of Environmental Restoration and Waste Management Under DOE Idaho Operations Office

Contract DE-AC07-76ID01570 


\begin{abstract}
This report documents the hazards assessment for the INEL Landfill Complex (LC) located at the Idaho National Engineering Laboratory, which is operated by EG\&G Idaho, Inc., for the U.S. Department of Energy (DOE). The hazards assessment was performed to ensure that this facility complies with DOE and company requirements pertaining to emergency planning and preparedness for operational emergencies. DOE Order 5500.3A requires that a facility-specific hazards assessment be performed to provide the technical basis for facility emergency planning efforts. This hazards assessment was conducted in accordance with DOE Headquarters and the DOE Idaho Operations Office (DOE-ID) guidance to comply with DOE Order 5500.3A. The hazards assessment identifies and analyzes the hazards that are significant enough to warrant consideration in a facility's operational emergency management program. The area surrounding the LC, the buildings and structures at the LC, and the processes that are used at the LC are described in this report. All hazardous materials, both radiological and nonradiological, at the LC were identified and screened against threshold quantities according to DOE Order 5500.3A guidance. Asbestos at the Asbestos Pit was the only hazardous material that exceeded its specified threshold quantity. However, the type of asbestos received and the packaging practices used are believed to limit the potential for an airborne release of asbestos fibers. Therefore, in accordance with DOE Order 5500.3A guidance, no further hazardous material characterization or analysis was required for this hazards assessment.
\end{abstract}




\section{CONTENTS}

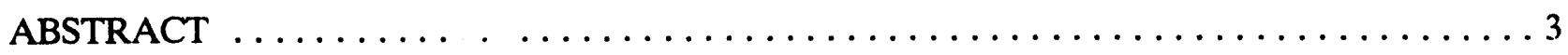

1. INTRODUCTION $\ldots \ldots \ldots \ldots \ldots \ldots \ldots \ldots \ldots \ldots \ldots \ldots \ldots \ldots \ldots \ldots$

2. FACILITY AND SITE DESCRIPTION $\ldots \ldots \ldots \ldots \ldots \ldots \ldots \ldots \ldots \ldots \ldots \ldots$

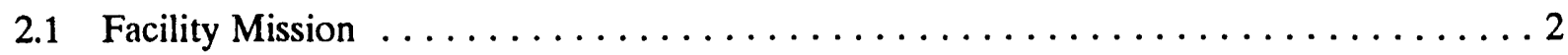

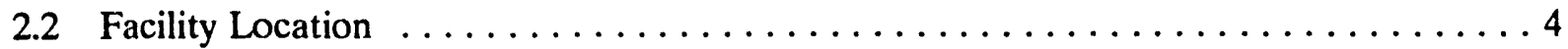

2.3 Facility Description $\ldots \ldots \ldots \ldots \ldots \ldots \ldots \ldots \ldots \ldots \ldots \ldots \ldots \ldots \ldots$

2.4 Processes and Operations for the INEL Landfill Complex $\ldots \ldots \ldots \ldots \ldots \ldots$

3. HAZARDOUS MATERIAL IDENTIFICATION $\ldots \ldots \ldots \ldots \ldots \ldots \ldots \ldots \ldots \ldots$

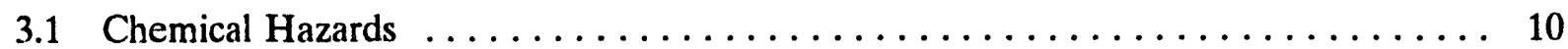

3.2 Radiological Hazards $\ldots \ldots \ldots \ldots \ldots \ldots \ldots \ldots \ldots \ldots \ldots \ldots \ldots \ldots \ldots \ldots$

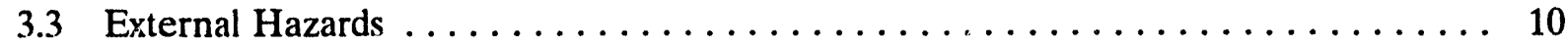

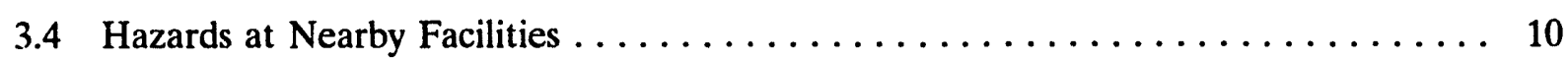

4. HAZARDOUS MATERIAL SCREENING $\ldots \ldots \ldots \ldots \ldots \ldots \ldots \ldots \ldots \ldots$

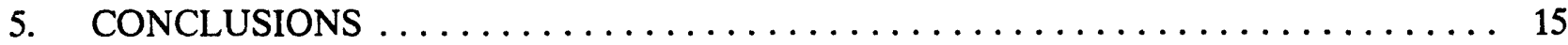

6. MAINTENANCE AND REVIEW OF THIS HAZARDS ASSESSMENT $\ldots \ldots \ldots \ldots 16$

7. REFERENCES $\ldots \ldots \ldots \ldots \ldots \ldots \ldots \ldots \ldots \ldots \ldots \ldots \ldots \ldots \ldots \ldots$

Appendix A-Prohibited Items at the INEL Landfills $\ldots \ldots \ldots \ldots \ldots \ldots \ldots \ldots \ldots \ldots$

FIGURES

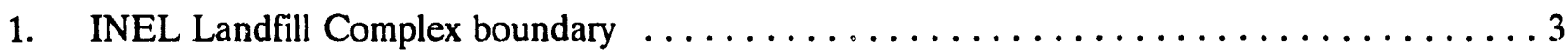

2. Location of the INEL Landfill Complex $\ldots \ldots \ldots \ldots \ldots \ldots \ldots \ldots \ldots \ldots \ldots$

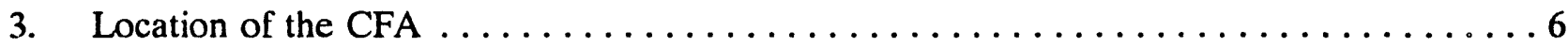

4. Location of the INEL $\ldots \ldots \ldots \ldots \ldots \ldots \ldots \ldots \ldots \ldots \ldots \ldots \ldots \ldots$ 


\section{TABLES}

1. INEL Landfill Complex hazardous materials inventory $\ldots \ldots \ldots \ldots \ldots \ldots \ldots \ldots \ldots$ 


\section{Hazards Assessment for the INEL Landfill Complex}

\section{INTRODUCTION}

This report documents the hazards assessment for the INEL Landfill Complex (LC) located at the Idaho National Engineering Laboratory (INEL), which is operated by EG\&G Idaho, Inc., for the Department of Energy (DOE). The hazards assessment was conducted in accordance with guidance from DOE Headquarters ${ }^{1}$ and DOE Idaho Operations Office (DOE-ID) ${ }^{2}$ to comply with DOE Order 5500.3A, "Planning and Preparedness for Operational Emergencies," ${ }^{3}$ which requires a facility-specific hazards assessment to provide the technical basis for facility emergency planning efforts. This hazards assessment identifies and analyzes the hazards that are significant enough to warrant consideration in a facility's operational emergency management program.

This report describes the $\mathrm{LC}$, the area surrounding the $\mathrm{LC}$, the buildings and structures located within the LC boundary, and the processes involved with the operation of the LC. Also, all hazardous materials stored, used, or produced at the LC are identified in this report. The hazards were screened in accordance with DOE Order 5500.3A guidance. The results of the screening are presented. 


\section{FACILITY AND SITE DESCRIPTION}

As stated in the INEL Site Development Plan, ${ }^{4}$ the INEL encompasses $2,300 \mathrm{~km}^{2}\left(890 \mathrm{mi}^{2}\right)$ of the northwestern portion of the Eastern Snake River Plain in southeastern Idaho. The INEL is nearly $63 \mathrm{~km} \mathrm{(39} \mathrm{mi)} \mathrm{long} \mathrm{from} \mathrm{north} \mathrm{to} \mathrm{south} \mathrm{and} \mathrm{about} 58 \mathrm{~km}(36 \mathrm{mi})$ wide in its broadest portion. The INEL includes portions of five Idaho counties (Bingham, Bonneville, Butte, Clark, and Jefferson). The INEL was established in 1949 by the U.S. Government to build, test, and operate developmental nuclear reactors and related facilities. New facilities have since been built and original buildings have been modified to accommodate testing and data gathering for reactor safety experiments, fuel studies, boiling water reactors, breeder reactors, aircraft nuclear propulsion, naval reactors, waste management programs, geothermal research, and environmental research.

The INEL is a limited access area about $72 \mathrm{~km}(45 \mathrm{mi})$ west of Idaho Falls, Idaho. The INEL was divided into distinct and geographically separate functional areas for programmatic necessity and operational efficiency. One of these areas is the Central Facilities Area (CFA). CFA consists of facilities that provide centralized support services for programmatic and nonprogrammatic efforts for the INEL. One of the support services is the LC. The LC consists of several areas at CFA that are used for the disposal of clean waste generated at the INEL; the LC also provides support for the INEL recycling program.

\subsection{Facility Mission}

Figure 1 shows the different areas used as landfills at the INEL. The dates of operation and mission for each one of these landfills are as follows:

- Landfill I was operated from the late 1940 s to the late $1960 \mathrm{~s}$. This landfill was used to dispose municipal solid sanitary waste, as regulated by 40 CFR 257 and 258 , that was generated at the INEL. This landfill has been covered with the required amount of fill material and is inspected yearly.

- Landfill II was operated from the late 1960s to approximately 1977. This landfill was also used to dispose municipal solid sanitary waste, as regulated by 40 CFR 257 and 258 , that was generated at the INEL. This landfill has also been covered with the required amount of fill material and is inspected yearly.

- Landfill III was operated from approximately 1977 to 1985 . This landfill was also used to dispose municipal solid sanitary waste, as regulated by 40 CFR 257 and 258, that was generated at the INEL. This landfill has also been covered with the required amount of fill material and is inspected yearly.

- Landfill III Extension was opened in approximately 1985 and is still being used. This landfill is used to dispose of industrial/commercial solid sanitary waste, as regulated by 40 CFR 258, that is generated at the INEL. 

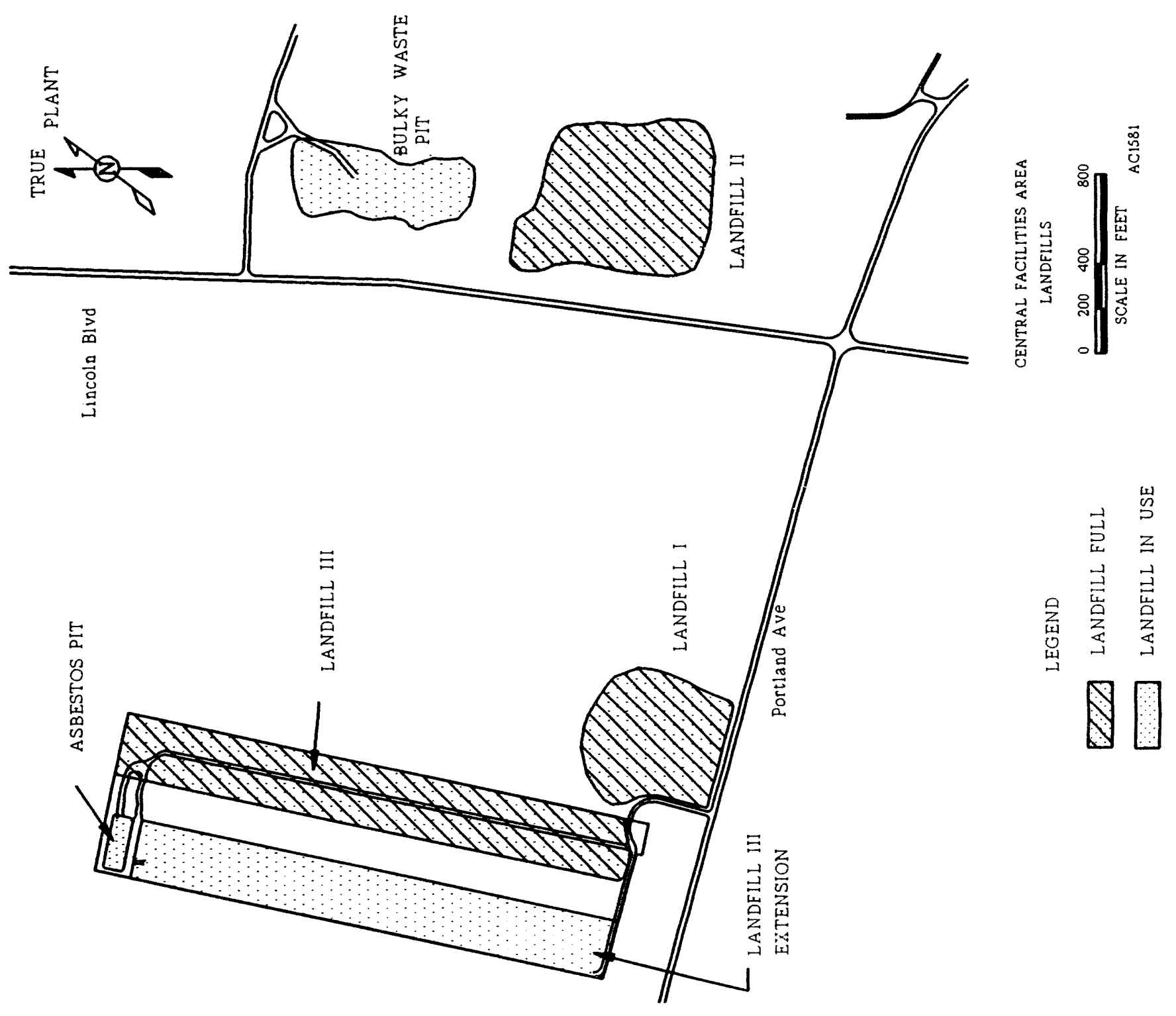

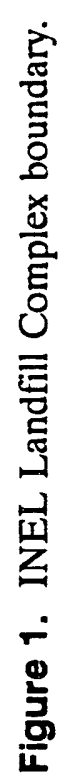


- The Asbestos Pit was opened in approximately 1978 and is still in operation. The Asbestos Pit is used to dispose of asbestos and asbestos-bearing materials that were used at the INEL.

- The Bulky Waste Pit was opened in 1987 and is still in operation. The Bulky Waste Pit is used to dispose of clean nonradioactive/noncontaminated earth materials and industrial/commercial solid sanitary waste, as regulated by 40 CFR 258 , that is generated at the INEL.

\subsection{Facility Location}

All of the landfills in the LC are located northwest of CFA. Figure 2 shows the location of the LC with respect to the other buildings at CFA. The location of CFA on the INEL is shown in Figure 3. Figure 4 shows the location of the INEL and approximate distances to cities and towns in the region. Figures 3 and 4 show the public access points, and roadways for transportation to and from the site and while traveling in the site boundary, and other facilities located within the site boundary. The LC is located in Butte County.

\subsection{Facility Description}

For this hazards assessment, the LC consists of six landfill pits, two trailers, three cargo containers, and one building. The landfills are shown in Figure 1. (Structures are not shown)

Landfill I is adjacent to West Portland, approximately $0.5 \mathrm{~km}(0.3 \mathrm{mi})$ west of the Portland and Lincoln Boulevard intersection.

Landfill II is adjacent to Lincoln Boulevard, approximately $0.24 \mathrm{~km}(0.15 \mathrm{mi})$ northeast of the Portland and Lincoln Boulevard intersection.

The Bulky Waste Pit is located adjacent to Lincoln Boulevard, approximately $0.5 \mathrm{~km}(0.3 \mathrm{mi})$ northeast of the West Portland and Lincoln Boulevard intersection. The Bulky Waste Pit is $732 \mathrm{~m}$ $(2,400 \mathrm{ft})$ long and $46 \mathrm{~m}(150 \mathrm{ft})$ wide. A trench at the Bulky Waste Pit has been excavated to approximately 6 to $7.5 \mathrm{~m}(20$ to $25 \mathrm{ft})$ deep.

Landfill III, Landfill III Extension, and the Asbestos Pit are all located in the same area. This entire landfill area is located adjacent to West Portland, approximately $0.7 \mathrm{~km}(0.45 \mathrm{mi})$ west of the Portland and Lincoln Boulevard intersection. This landfill area is approximately $732 \mathrm{~m}(2,400 \mathrm{ft})$ long by $152 \mathrm{~m}(500 \mathrm{ft})$ wide and has a $1.8 \mathrm{~m}(6 \mathrm{ft})$ high chain link fence around its perimeter. This area has grid markings to identify the location of disposed waste. The grid consists of posts spaced $30.5 \mathrm{~m}(100 \mathrm{ft})$ apart south to north marked with the letters $\mathrm{A}$ through $\mathrm{X}$ and post spaced $15.2 \mathrm{~m}$ (50 $\mathrm{ft}$ ) apart east to west marked with the numbers 10 through 19. Landfill III is approximately $700 \mathrm{~m}(2,300 \mathrm{ft})$ long by $61 \mathrm{~m}(200 \mathrm{ft})$ wide. Landfill III Extension is approximately $700 \mathrm{~m}$ $(2,300 \mathrm{ft})$ long by $91 \mathrm{~m}(300 \mathrm{ft})$ wide. Landfill III Extension consists of six trenches, each $15.2 \mathrm{~m}$ $(50 \mathrm{ft})$ wide by $700 \mathrm{~m}(2,300 \mathrm{ft})$ long and excavated to approximately 7.5 to $9.2 \mathrm{~m}(25$ to $30 \mathrm{ft})$ deep. The Asbestos Pit is located at the north end of the landfill and is positioned between grid markings $\mathrm{W}$ and $\mathrm{X}$, and extends across the ends of trenches 10 through 19. The Asbestos Pit is 


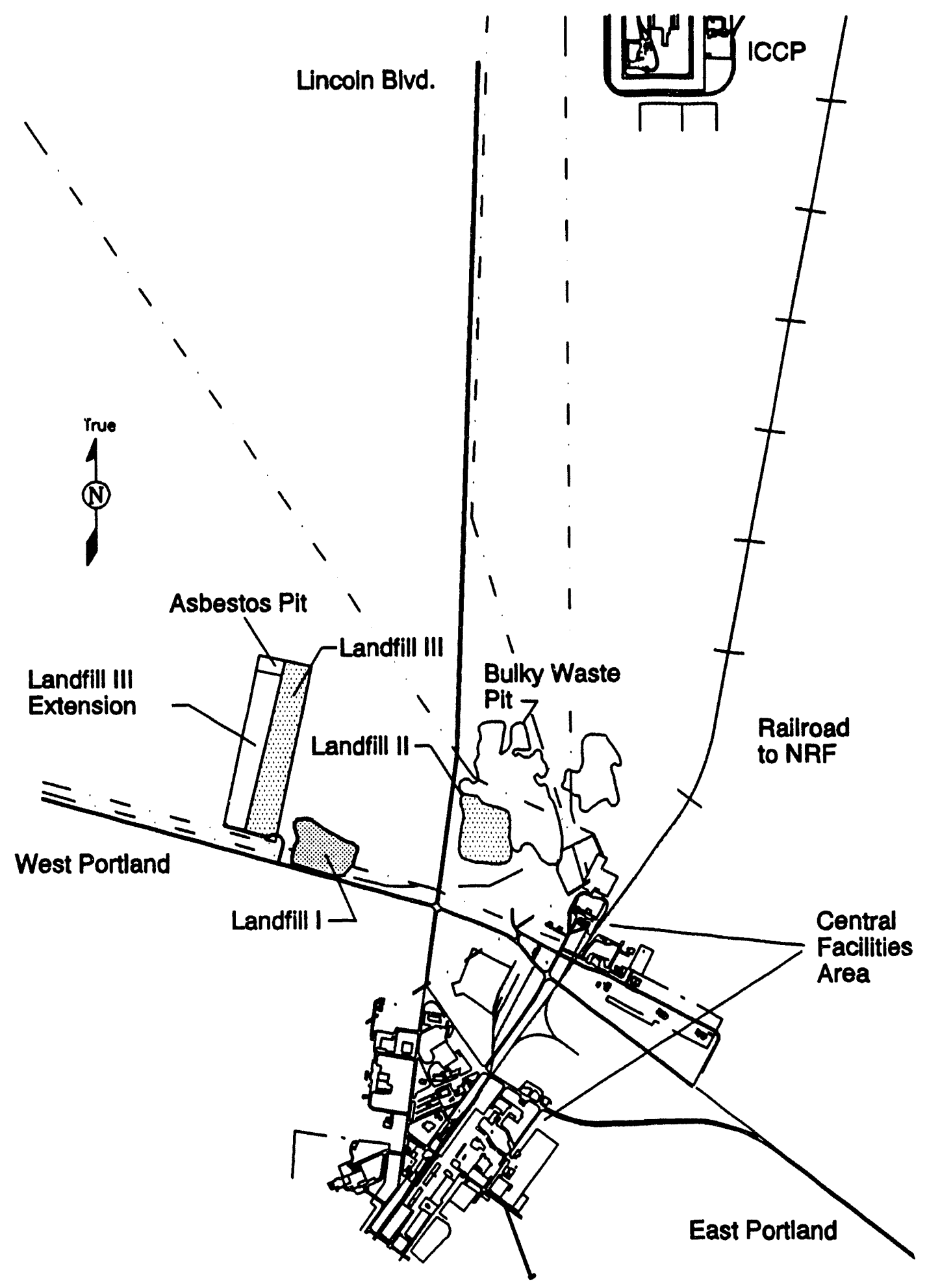

Figure 2. Location of the INEL Landfill Complex. 


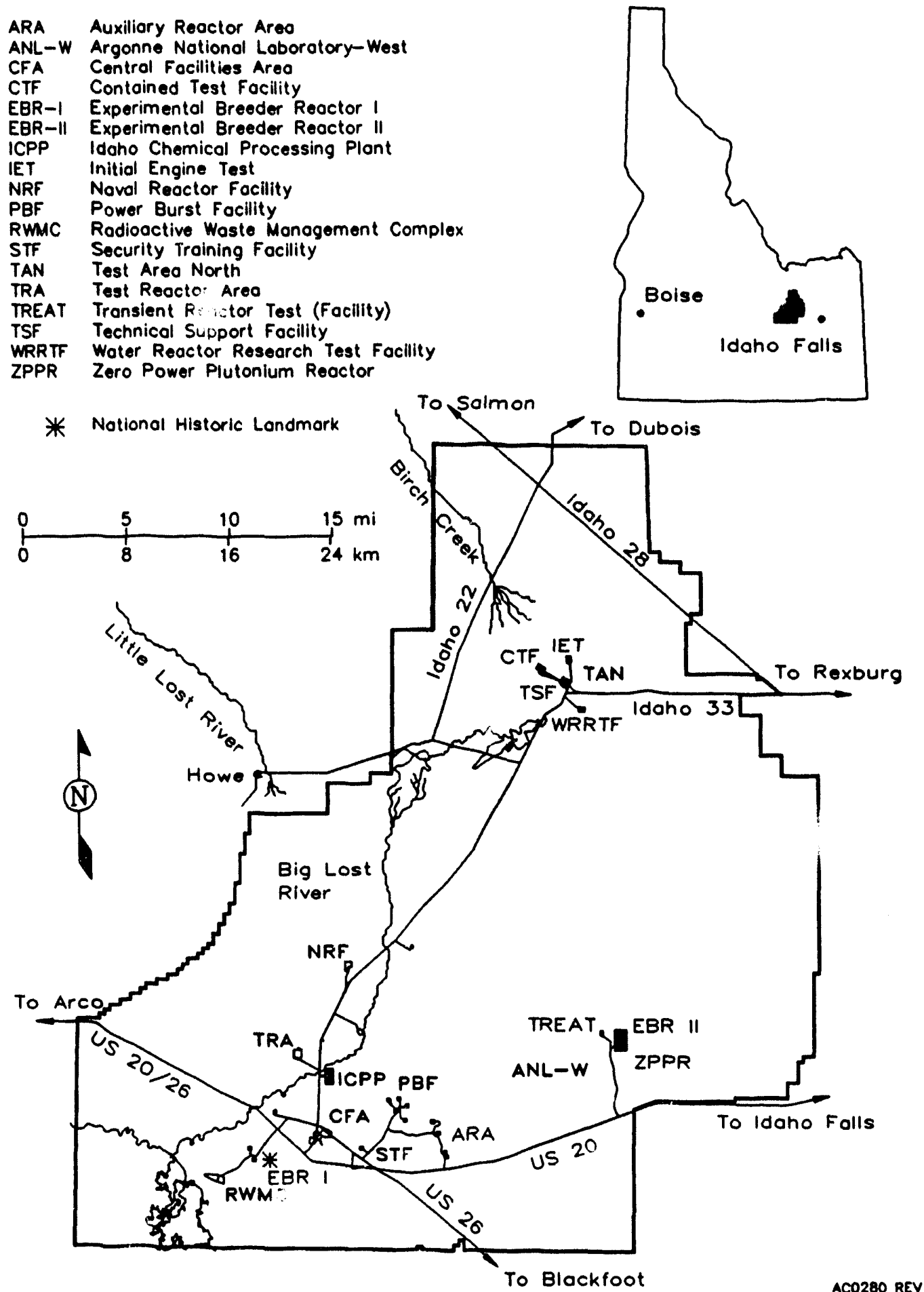

Figure 3. Location of the CFA. 


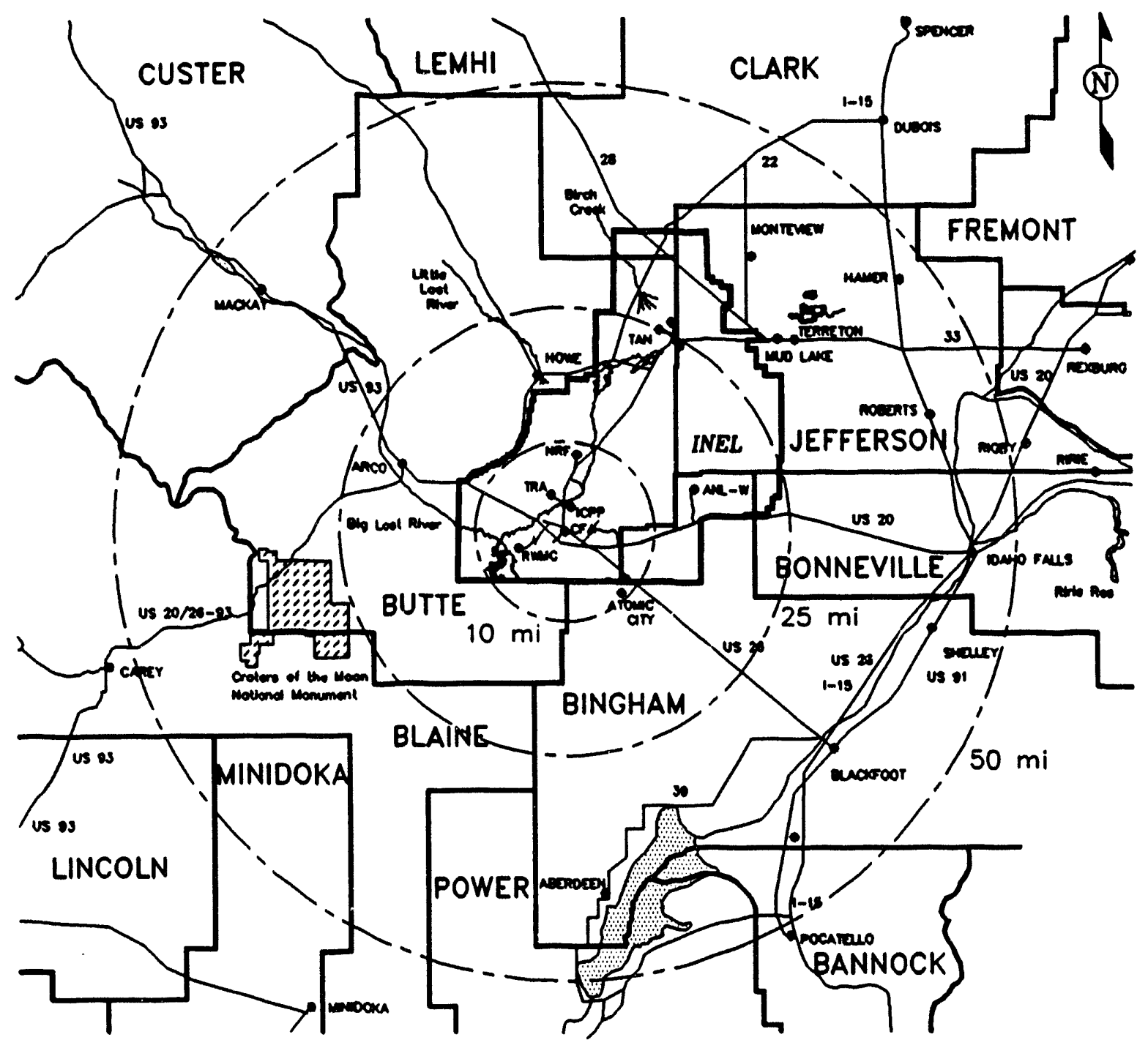

LEGEND

$--10,25,50 \mathrm{mi}$

from Central Focilities Areo

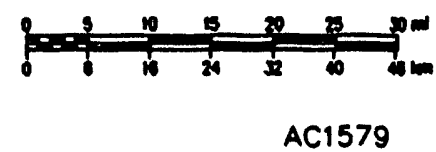

Figure 4. Location of the INEL. 
approximately $30.5 \mathrm{~m}(100 \mathrm{ft})$ long by $152 \mathrm{~m}(500 \mathrm{ft})$ wide. This pit is excavated to approximately $6 \mathrm{~m}(20 \mathrm{ft})$ deep.

A trailer and a cargo container are located south of the landfill. Also, located to the west of the landfill is a small building, a trailer, and two cargo containers.

The two trailers are 2.4 by $6 \mathrm{~m}(8$ by $20 \mathrm{ft}$ ) and have a conventional mobile home frame construction. The trailers are currently being used as offices. There is a $757 \mathrm{~L}$ ( 200 gal) propane

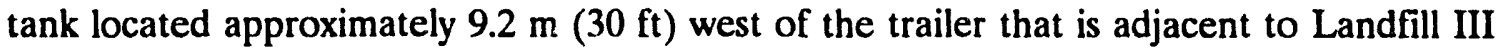
Extension.

The three steel cargo containers are $2.7 \mathrm{~m}(9 \mathrm{ft})$ wide by $9.2 \mathrm{~m}(30 \mathrm{ft})$ long by $2.4 \mathrm{~m}(8 \mathrm{ft})$ high. One cargo container (west of Landfill III Extension) is used as a mechanical shop while the other two are used for storage. Four fire proof cabinets are located outside the two cargo containers by the Landfill III Extension.

The building is 3 by $3 \mathrm{~m}$ (10 by $10 \mathrm{ft}$ ) and is constructed of wood. An eye wash station, a fire proof cabinet, and two self-contained breathing apparatus are located inside this building.

\subsection{Processes and Operations for the INEL Landfill Complex}

The processes at each of the three landfills still in use are slightly different. The staffing for the three landfills is approximately 15 to 20 personnel during normal working hours.

The process at the Landfill III Extension is to receive and dispose of clean nonradioactive/noncontaminated and nonhazardous solid waste. Solid waste is delivered in either dumpmaster trucks, chain truck, or other trucks and/or trailers. Compactable waste (e.g., paper and boxes) are typically delivered on the dumpmaster trucks. Chain trucks are used to deliver noncompactable waste [e.g., scrap metal less than $2.4 \mathrm{~m}(8 \mathrm{ft})$ long]. All waste is dumped at the lip of the trench, spread, inspected, compacted, and covered with fill material (dirt and gravel) daily. Waste is spread with a bulldozer if it is not already spread by off-loading. A visual inspection is performed to identify and remove prohibited items. Items prohibited from disposal at the lanc . are listed in Appendix A. Also, the LC health physicist performs radiological surveys of the v. , te to ensure that the waste is less than 100 counts above background.

The process at the Asbestos Pit is to receive and dispose of asbestos and asbestos-bearing materials. Asbestos and asbestos-bearing materials are typicali ceived in pre-packaged 1.2 by 1.2 by $2.4 \mathrm{~m}$ ( 4 by 4 by $8 \mathrm{ft}$ ) plywood boxes. Generators of the asbcitos waste load plywood boxes with asbestos and asbestos-bearing material that has been sealed in double or triple polyethylene bags. Filled plywood twixes are sealed, nailed, and banded (with three metal bands) before being shipped to the landfill. Occasionally, small shipments of asbestos-bearing material is received at the LC in double or triple polyethylene bags. These small shipments are placed into a plywood box which is then sealed, nailed, and banded (with three metal bands) once filled.

Plywood boxes received at the Asbestos Pit are delivered on flatbed trucks or trailers. The plywood boxes are off-loaded with a forklift or crane, depending on the weight. The plywood boxes are stacked two high in the pit. Once six plywood boxes have been placed in the pit (three 
rows of one deep and two high), the plywood boxes are covered with $0.6 \mathrm{~m} \mathrm{(} 2 \mathrm{ft}$ ) of earthen material. Before being landfilled, the asbestos waste is visually inspected and radiologically surveyed.

The process at the Bulky Waste Pit is to receive and dispose of solid waste [e.g., concrete and scrap metal longer than $2.4 \mathrm{~m}(8 \mathrm{ft})$ ]. All waste is dumped or off-loaded at the lip of the pit, inspected, radiologically surveyed, pushed into the pit, and covered with fill material.

Abnormal operating procedures are conducted upon receipt of prohibited items at the landfill. When prohibited items are found in a load of waste, operations are curtailed. The generator is notified of such items and shall respond to colleci these items and clean up any nonconformance before normal operations are resumed.

The LC is also in charge of recycling mixed paper products and cardboard at the CFA. Recycling bins are placed at CFA facilities for collecting mixed paper products and cardboard. The recycling bins are periodically checked by LC personnel to determine if the bins need to be emptied. Filled recycling bins are inspected, surveyed for radiological hazards, and emptied into dumpmaster trucks. The mixed paper products and cardboard are then hauled offsite to a local recycling vendor. 


\section{HAZARDOUS MATERIAL IDENTIFICATION}

The chemical, radiological, external, and nearby facility hazards associated with the LC have been identified and are discussed in this section.

\subsection{Chemical Hazards}

The hazardous materials stored, used, and produced at the LC have been identified from the LC Hazardous Agent Inventory (inventory dated March 29, 1993). In addition, a walkdown of the facility was conducted on April 19,1993, with a cognizant LC facility representative to update the inventory and verify that the updated inventory was complete and accurate. The updated inventory is listed in Table 1.

\subsection{Radiological Hazards}

There are no radiological hazards stored, used, or produced at the LC.

\subsection{External Hazards}

Natural phenomena hazards associated with the LC are earthquakes, floods, winds, tornadoes, lightning strikes, volcanism, range fires, and heavy snow. These natural phenomena have the potential to impact the operations that take place at the LC. The only hazardous material that might be released due to any of these natural phenomena is asbestos. The hazards associated with the type of asbestos received at the LC are discussed in a following section.

\subsection{Hazards at Nearby Facilities}

The Idaho Chemical Processing Plant (ICPP), Advanced Test Reactor (ATR), and some facilities at CFA contain hazardous materials (radiological and nonradiological) that if released may cause an evacuation of personnel at the LC. However, hazards at these nearby facilities do not have the potential to cause a release of any hazardous materials contained at the LC. 
Table 1. INEL Landfill Complex hazardous materials inventory.

Hazardous agent

Quantity

Location of the hazardous agent

Asbestos

Unknown $^{\mathrm{a}}$

Asbestos pit

Acetylene

1 cylinder

Service truck

Ammonium phosphate

(ABC fire ext.)

6 hand-held

cylinders

Trailers, eye wash building, cargo container, two extinguisher stations

Ali umatic transmission fluid

Dexron II

45 qt (max)

Fireproof cabinet in the cargo container

Battery acid

10 batteries (max)

Vehicles on site

Chevron Declo 400 motor oil SAE 3010 gal (max)

Compublend II glass cleaner

$6 \mathrm{qt}(\max )$

Fireproof cabinet in the cargo container

Diesel fuel \#2

$500 \mathrm{gal}(\max )$

Diesel fuel

$20 \mathrm{gal}(\max )$

Trailer at main entrance

Aboveground tank west of Pit III Extension

Fireproof cabinet in the cargo container

Dyco Snow \& Ice Buster

$40 \mathrm{lb}$ (max)

Trailer at main entrance

Envy cleaner

3 gal (max)

Janitor's vehicle

Ethylene glycol

10 gal (max)

Fireproof cabinet in the cargo container

Fire extinguisher, $\mathrm{BC}$

6 hand-held

cylinders

Trailers, eye wash building, cargo container, and two extinguisher stations

Floor Dry $\quad 200 \mathrm{lb}(\max )$

Fireproof cabinet in the cargo container

Gasoline, auto, unleaded

100 gal (max)

Vehicles on site

Gasoline, leaded

25 gal (max)

Fireproof cabinet in the cargo container

Hand cream

$32 \mathrm{oz}(\max )$

Both trailers

Hand cream, Sani-Fresh

$100 \mathrm{oz}$ (max)

Both trailers

Hydraulic brake fluid

10 gal (max)

Service truck

Lead acid batteries

10 batteries (max) 
Table 1. (continued).

\begin{tabular}{|c|c|c|}
\hline Hazardous agent & Quantity & Location of the hazardous agent \\
\hline Lemon Shine-up & 1 al (max) & Janitor's vehicle \\
\hline Multi-purpose grease & $350 \mathrm{oz}(\max )$ & $\begin{array}{l}\text { Fireproof cabinet in the cargo } \\
\text { container }\end{array}$ \\
\hline Oxygen, compressed gas & 2 cylinders & Eye wash building, used for SCBA \\
\hline Portland cement & $90 \mathrm{lb}(\max )$ & Cargo container \\
\hline Propane & 200 gal (max) & West of Pit III Extension trailer \\
\hline Propane & 5 gal (max) & $\begin{array}{l}\text { Fireproof cabinet in the cargo } \\
\text { container }\end{array}$ \\
\hline Renuzit air freshener & $96 \mathrm{oz}(\max )$ & Trailer at main entrance \\
\hline Rislone concentrate & 3 qt $(\max )$ & Service truck \\
\hline Rust-Oleum & 180 oz (max) & $\begin{array}{l}\text { Fireproof cabinet in the cargo } \\
\text { container }\end{array}$ \\
\hline Rust-Oleum paint & $1 / 2 \operatorname{gal}(\max )$ & $\begin{array}{l}\text { Fireproof cabine: in the cargo } \\
\text { container }\end{array}$ \\
\hline Sodium bicarbonate (baking soda) & $16 \mathrm{oz}(\max )$ & Service truck \\
\hline Starting fluid & $108 \mathrm{oz}(\max )$ & $\begin{array}{l}\text { Fireproof cabinet in the cargo } \\
\text { container }\end{array}$ \\
\hline Super Blue II & $6 \mathrm{oz}$ & $\begin{array}{l}\text { Fireproof cabinet in the cargo } \\
\text { container }\end{array}$ \\
\hline Tap-All & $6 \mathrm{oz}(\max )$ & Service truck \\
\hline Thrust Quick starting fluid & $120 \mathrm{oz}(\max )$ & $\begin{array}{l}\text { Fireproof cabinet in eye wash } \\
\text { building }\end{array}$ \\
\hline Unocal Guardol motor oil $15 \mathrm{~W} / 40$ & $10 \mathrm{gal}(\max )$ & $\begin{array}{l}\text { Fireproof cabinet in the cargo } \\
\text { container }\end{array}$ \\
\hline Unocal MP gear lube & 55 gal (max) & Cargo container \\
\hline Unocal multipurpose ATF Dextron & 12 qt (max) & $\begin{array}{l}\text { Fireproof cabinet in the cargo } \\
\text { container }\end{array}$ \\
\hline Unocal UNAX AW 32 & 55 gal (max) & Service truck \\
\hline WD-40 & $1 \mathrm{qt}(\max )$ & $\begin{array}{l}\text { Fireproof cabinet in the cargo } \\
\text { container }\end{array}$ \\
\hline Windex glass cleaner & $64 \mathrm{oz}(\max )$ & Trailer at main entrance \\
\hline
\end{tabular}


Table 1. (continued).

Hazardous agent Quantity Location of the hazardous agent

Windshield washer solvent

$10 \mathrm{gal}(\max ) \quad$ Cargo container

$3 \mathrm{M}$ brand A-101 spray cleaner $64 \mathrm{oz}(\max ) \quad$ Janitor's vehicle

300 Flow Plus

15 qt (max)

Fireproof cabinet in the cargo container

a. Specific quantity of asbestos is not known. Shipping records indicate only gross weight of disposed plywood boxes. 


\section{HAZARDOUS MATERIAL SCREENING}

The hazardous materials were screened according to DOE Order 5500.3A guidance. DOE guidance states that a screening or threshold quantity (TQ) should be used to eliminate the need to analyze insignificant hazards. The guidance states that the threshold planning quantity (TPQ) defined by the EPA Superfund Amendment and Reauthorization Act (SARA) Title III, 40 CFR Part 355, Appendix A, may be used as TQs for those chemicals listed. In addition, the reportable quantity (RQ) from SARA Title III Consolidated List of Chemicals, 40 CFR Part 302, Table 302.4, was also used as a TQ in the screening process. The TQ screening criteria for radioactive materials was from 10 CFR 30.72 , Schedule C.

Of the hazardous materiais identified at the LC, the only hazardous material that may exceed

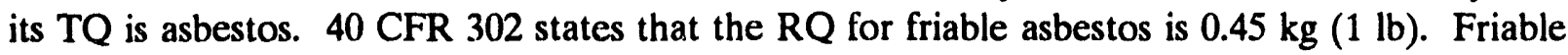
asbestos is any material containing more than one percent asbestos that, when dry, can be crumbled, pulverized, or reduced to powder by hand pressure. Disposal records for the Asbestos Pit were reviewed to determine if a quantity of friable asbestos could be estimated.

Asbestos and asbestos-bearing materials have been disposed of in the Asbestos Pit since approximately 1978. Before 1991, disposal records for all the landfill pits at the LC were kept in one log book. After 1991, disposal records were kept in separate log books for the various landfill pits. The disposal records after 1991 were reviewed. The disposal records indicate the type of asbestos-bearing material (i.e., tiles, piping, and backing material) and the gross quantity of waste contained in each plywood box. The disposal records do not indicate the quantity or percentage of asbestos contained in the disposed materials. Also, the disposal records do not indicate whether the disposed waste contained friable or nonfriable asbestos. However, zognizant LC representatives concurred that a majority of the asbestos waste is nonf:iable asbestos.

Cognizant LC representatives also indicated that the asbestos vaste is thoroughly packaged and sealed to prevent any type of airborne release of asbestos fibers. Asbestos and asbestos-bearing materials are wetted, wrapped in double or triple polyethylene bags, and then placed in plywood boxes that are sealed, nailed, and banded with three metal bands. The plywood

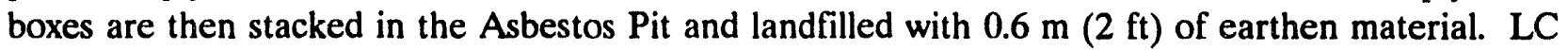
representatives strongly felt that because of the type of asbestos waste and the packaging of the waste, a release of friable asbestos is highly unlikely. Therefore, asbestos will be screened from further characterization and analysis. 


\section{CONCLUSIONS}

Upon completion of hazards identification and screening, it was determined that asbestos was the only material that may exceed its TQ. The quantity of friable asbestos at the LC is not known. However, cognizant LC representatives concurred that a majority of the asbestos waste is nonfriable asbestos. In addition, LC representatives indicated that the asbestos waste is thoroughly packaged and sealed to prevent any type of airborne release of asbestos fibers. The asbestos waste is wetted, wrapped in double or triple polyethylene bags, and placed inside plywood boxes that are sealed, nailed, and banded with three metal bands. The plywood boxes are then stacked in the

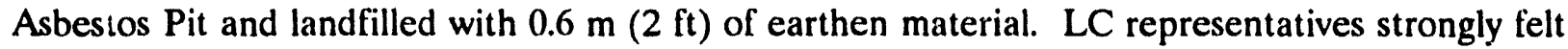
that because of the type of asbestos waste and the packaging of the waste, a release of friable asbestos is highly unlikely. Therefore, no further characterization or analysis will be performed.

However, LC personnel should be fully aware of the hazards associated with asbestos. Personnel should be very cautious following any event that causes a breach of the plywood boxes. All nonessential personnel should be evacuated from the area if a plywood box is breached. 


\section{MAINTENANCE AND REVIEW OF THIS HAZARDS ASSESSMENT}

The Waste Reduction Operation Complex (WROC) Management is responsible for ensuring that the LC hazards assessment is regularly reviewed and maintained current. The review requirement and schedule is specified in the Site Emergency Readiness Assurance Plan.

The LC hazards assessment is a controlled document and is subject to Configuration Control. Configuration Control is the process of managing documents to ensure that they are adequately defined, evaluated, reviewed, and approved. At WROC, a Configuration Management (CM) coordinator has been assigned to coordinate the disciplined implementation of configuration management. The CM coordinator knows LC systems, components, and documents and ensures that changes are managed in accordance with approved procedures. The $\mathrm{CM}$ coordinator identifies the change that needs to be made, ensures that proper review and approval are obtained, ensures that other affected documentation is identified, and follows up to ensure that the change has been implemented. Changes to facility documentation and equipment are documented in drawing revision requests, document change notices, and facility change forms. The Unreviewed Safety Question $^{5}$ (USQ) process interfaces with CM through these documents, which implement the requirement to perform a USQ evaluation as a part of the change control process. 


\section{REFERENCES}

1. U.S. Department of Energy, Office of Emergency Preparedness and Response and Office of Emergency Planning and Operations, "Emergency Management Guidance," memorandum to Distribution, June 29, 1992.

2. J. A. Jones, Chief Occupational Safety and Emergency Management Branch DOE-ID, To Contractor Distribution, Subject: "Issuance of Hazards Assessment Guidance AM/SES-OEM-92-206," October 7, 1992.

3. DOE Order 5500.3A. "Planning and Preparedness for Operational Emergencies," April 30, 1991.

4. EG\&G Idaho, Inc., Site Development Plan, Idaho National Engineering Laboratory, prepared for the U.S. Department of Energy, November 1990.

5. DOE Order 5480.21, "Unreviewed Safety Questions," December 24, 1991. 


\section{Appendix A}

\section{Prohibited Items at the INEL Landfills}




\section{Appendix A}

\section{Prohibited Items at the INEL Landfills}

The following items are prohibited from disposal at the landfill:

- Free liquids exceeding one gallon per container or any quantity of any unknown liquid. No free liquids is the goal.

- No free liquid quantities of volatile organic compounds.

- Radioactive/contaminated items that exceed the limits outlined in DOE-ID Order 5400.5, "Radiation Protection of the Public and the Environment," Chapter II, Section 5.c. This includes any material enhanced by a DOE Operation.

- $\quad$ "Mixed waste," as defined by DOE 5820.2A, "Radioactive Waste Management"

- Hazardous wastes, "listed" or "characteristic," as defined by 40 CFR 261

- Rubber tires (auto, truck)

- All batteries

- $\quad$ Printed circuit boards

- Mercury and sodium vapor lights

- $\quad$ Polychlorinated biphenyls above $25 \mathrm{ppm}$

- Lead

- $\quad$ Lead- and chrome-based paints

- Solder

- $\quad$ Scrap wood or metal, longer than $2.4 \mathrm{~m} \mathrm{(8 \textrm {ft } )}$

- Telephone cable

- Pesticides, herbicides, insecticides, and rodenticides

- Medical wastes consisting of medical sharps (anything sharp used to cut or scrape tissue, inject medicine, or draw blood, such as needles and scalpels)

- Liquid absorbed into an absorbent material such as kitty litter and floor dry. 
NOTE: Liquids (in excess of one gallon) must be solidified using cement or similar product to produce a solid form such as concrete. 

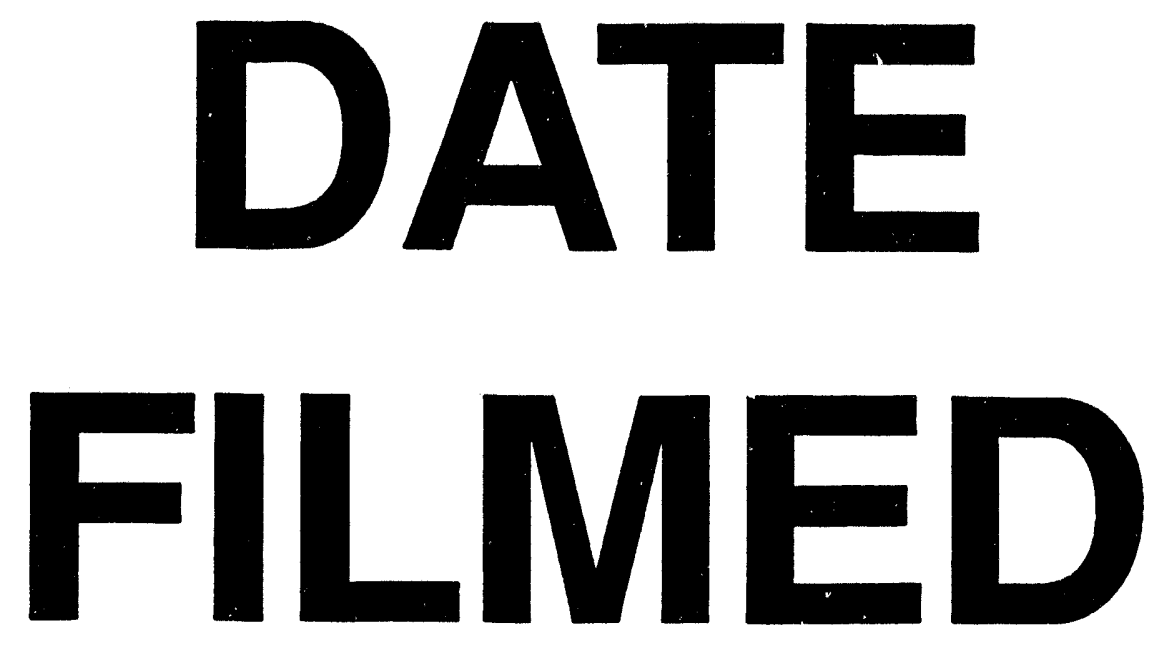

$$
8 / 23 / 94
$$
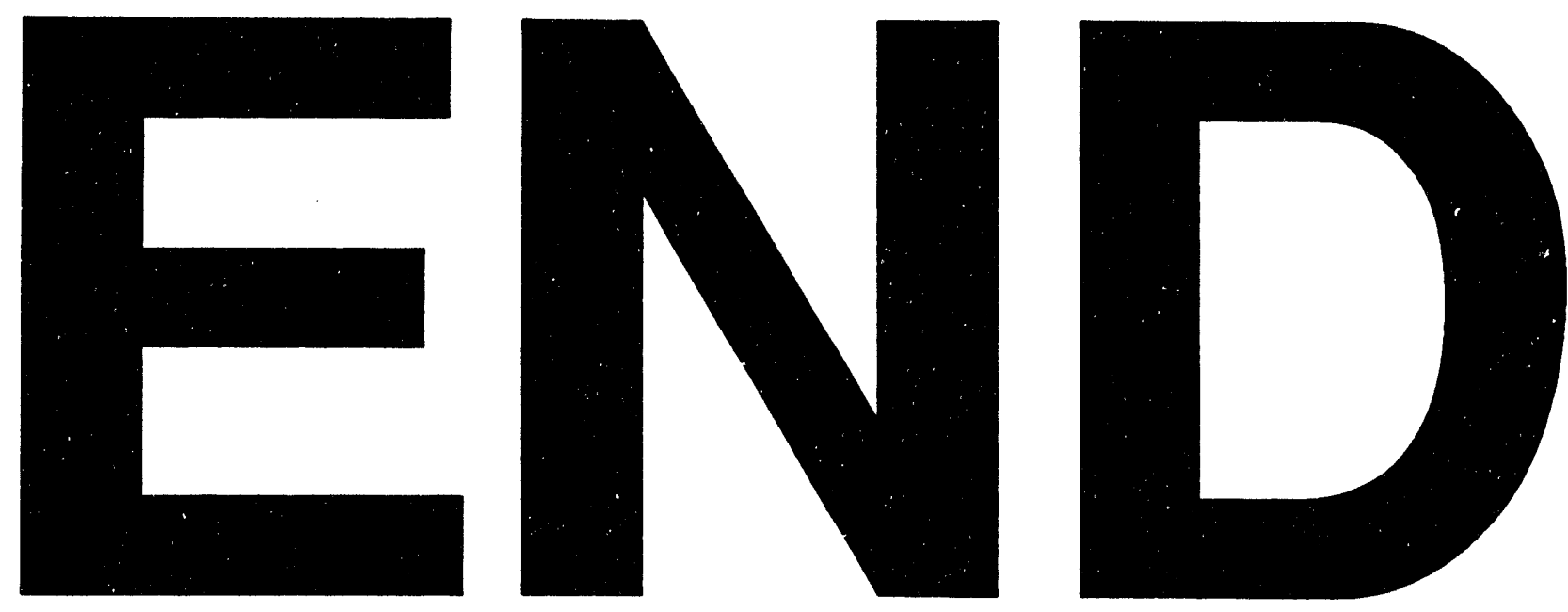